ENTREPRENEURSHIP AND SUSTAINABILITY ISSUES

ISSN 2345-0282 (online) http://jssidoi.org/jesi/ 2019 Volume 7 Number 1 (September) http://doi.org/10.9770/jesi.2019.7.1(1)

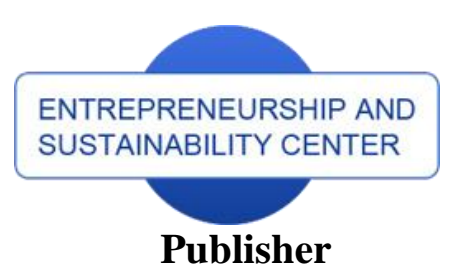

http://jssidoi.org/esc/home
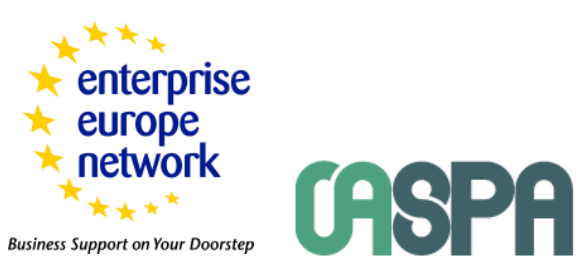

\title{
OCCUPATIONAL HEALTH AND SAFETY ASPECTS OF GREEN SHIPPING IN THE BALTIC SEA ${ }^{\star}$
}

\author{
Karin Reinhold ${ }^{1}$, Marina Järvis ${ }^{2}$, Gunnar Prause ${ }^{3}$ \\ $1,2,3$ \\ Tallinn University of Technology, Akadeemia tee 3, 12618 Tallinn, Estonia \\ *Corresponding author. Tel.: +372 56621387 \\ E-mails: ${ }^{{ }^{*} k a r i n . r e i n h o l d @ t a l t e c h . e e},{ }^{2}$ marina.jarvis@taltech.ee $;{ }^{3}$ gunnar.prause@taltech.ee
}

Received 15 January 2019; accepted 26 June 2019; published 30 September 2019

\begin{abstract}
After the implementation of the SECA regulation in BSR in 2015, one other step towards cleaner shipping will be the NECA regulation from 2021. Thus, green shipping is an important highlight on the Baltic Sea Region (BSR) environmental agenda. It is well known that shipping is one of the most international industries but it also represents one of the most dangerous businesses since maritime sector workers are often exposed to a number of occupational hazards such as difficult and uncontrolled climate conditions, emissions, noise, vibration, chemicals, and long hours of work in combination with rigid organisational structures, isolation and high levels of psychological stress. Maritime workers are often confronted with health problems, occupational diseases, incidents and occupational accidents. This sends a strong pointer that green shipping should also imply greener maritime jobs so that the work becomes safer for workers and corresponds to the global challenges of environmental protection, economic development and social inclusion. The presented research analyses the health and safety aspects of green shipping in the context of occupational health and safety (OSH) to identify set of indicators that are essential to be applied in green shipping. The central research question evaluates health and OSH risks of BSR inhabitants and seafarers to determine the extent to which the SECA regulations have helped to improve health and work related conditions in the BSR.
\end{abstract}

\footnotetext{
${ }^{\star}$ This work is in principle linked to the EnviSuM - Environmental Impact of Low Emission Shipping: Measurements and Modelling Strategies project sponsored by the European Regional Development Fund.
}
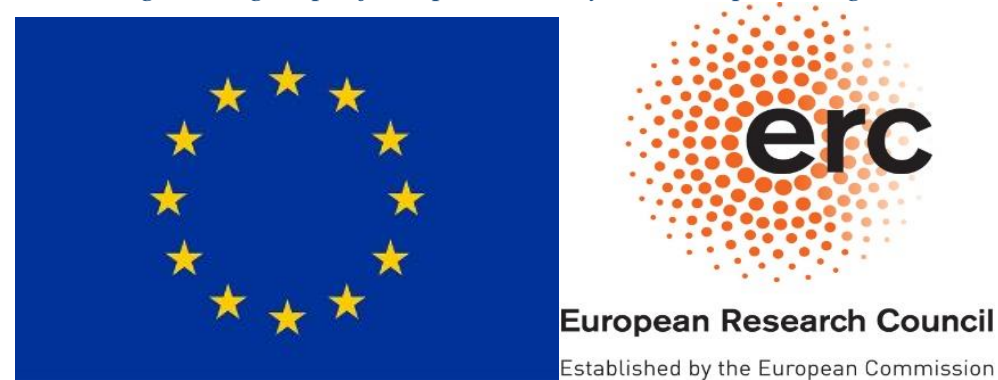


\section{ENTREPRENEURSHIP AND SUSTAINABILITY ISSUES}

ISSN 2345-0282 (online) http://jssidoi.org/jesi/ 2019 Volume 7 Number 1 (September) http://doi.org/10.9770/jesi.2019.7.1(1)

Keywords: SECA regulations; clean shipping; health and environmental impact; maritime occupational health and safety; socio-economic risks

Reference to this paper should be made as follows: Reinhold, K.; Järvis, M.; Prause, G. 2019. Occupational health and safety aspects of green shipping in the Baltic Sea, Entrepreneurship and Sustainability Issues 7(1): 10-24. http://doi.org/10.9770/jesi.2019.7.1(1)

JEL Classifications: G31, G32, L26, L98, M1

\section{Introduction}

Scientific studies show that air pollution from international shipping accounts for approximately 50,000 premature deaths every year in Europe (CEEH, 2011), which totals an annual social cost of over $€ 58$ billion (Underwood \& Waterson, 2013). Ship emissions contribute to air pollution through sulphur oxides (SOx), nitrogen oxides (NOx) as well as from fine particles, usually called particulate matter (PM), and black carbon causing negative health impacts of citizens. The particulate matter are linked to premature deaths because when they find through the lungs their way into the bloodstream and trigger inflammations which eventually cause heart and lung failure and could lead to cancer (Boffetta et al., 2001).

Consequently, the International Maritime Organization (IMO) and the European Parliament (EP) decided in 2005 and 2012 to establish the Sulphur Emission Control Areas (SECA) in Northern Europe where operating ships from 2015 must use fuel with a low sulphur content not exceeding 0.1\% (Knapp \& Franses, 2009). At the end of 2015, European Union approved in the frame of the BSR Interreg Programme the "EnviSuM (Environmental Impact of Low Emission Shipping Measurements and Modelling Strategies) project" to assess the technical efficiency and the socio-economic impacts of clean shipping solutions in the Baltic Sea Region (BSR). After three years of the project activities, some of the published results of the socio-economic impacts of the regulation focused majorly on emission measurements, the efficiency of abatement technologies and economic impacts of SECA regulations on the maritime stakeholders (Atari et al., 2019; Olaniyi, Atari \& Prause, 2018).

Before the introduction of SECA regulations in 2015, scholars intensively discussed the tentative impact for maritime stakeholders and estimated economic disadvantages from SECA areas due to high compliance costs for the strict environmental regulations compared to competitors in other parts of the world. Most experts forecasted a disproportionally increase of maritime transport costs in SECA regions initiating a cargo shift from sea to land transport so that shipping companies and ports would lose handling volumes and income. Other discussions argued that the regulations would weaken the competitiveness of European maritime transport especially in the modal shift of cargo flows from marine transport to inland transport routes of which, the implementation costs to the maritime sector up to $€ 11$ billion by 2020 (Prause \& Olaniyi, 2019).

The EU project "EnviSuM" with 12 partners from all over the Baltic Sea Region (BSR) investigated between 2016 and 2019 the impacts of the SECA regulations and found out that after 2015 no such significant changes are witnessed and that an impressive high level of compliance (ca. 95\%) within the BSR was measured. A BSR-wide survey among maritime stakeholders at the begin of the EnviSuM project showed no only neglectable impact of SECA regulations on BSR logistics sector and a later statistical analysis of foreign trade flows and maritime transport revealed no evidences for modal shifts or changes in transport patterns in BSR (Olaniyi \& Prause, 2019).

Even the no significant logistics pricing issues were detected since most of the vessels that operate in the Baltic Sea now use low sulphur maritime fuel that was since 2015 most of the time less expensive than the formerly used heavy fuel oil due to low oil prices. Latest results on the estimation of the administrative burden and a real option based evaluation of abatement technology investments by also showed neglectable impact on the maritime industry. 


\section{ENTREPRENEURSHIP AND SUSTAINABILITY ISSUES}

ISSN 2345-0282 (online) http://jssidoi.org/jesi/ 2019 Volume 7 Number 1 (September) http://doi.org/10.9770/jesi.2019.7.1(1)

Hence, the SECA regulation have not met the maritime sceptics that were expected before 2014 (Atari et al., 2019; Prause \& Olaniyi, 2019).

The results of the "EnviSuM" project also detected several benefit attached to the SECA regulations for the BSR, some of those include the increase of the air quality within BSR and the reduction of the annual emission of Sulphur into half. However, one benefit with most consequence is the 1000 less premature deaths experienced due to cleaner air and a push of blue growth innovation activities in BSR investigated (Barregard et al., 2019; Repka, 2019). Thus, the SECA regulations seem to have created more innovative technological awareness among the ship owners since its enforcement and generated an innovation push towards clean shipping technologies for BSR companies.

Until now, the socio-economic impact of SECA regulations have been discussed mainly with a focus on environmental and health aspects (Prause et al., 2019). However, the transition towards a green economy and the constant pressure on the economy and environmental issues has opened up new challenges for Occupational Health and Safety $(\mathrm{OSH})$ which includes potential exposure to traditional occupational risks, emerging risks from new technologies, working processes and workforce demographic changes (diverse workforce) (Lee \& Nam, 2017; Shabunina et al., 2017). This means that there is need to ensure that green jobs contribute to the protection of ecosystems and biodiversity, reduce energy, minimise materials and water consumption through high-efficiency strategies, de-carbonise the economy and minimise generation of all forms of waste and pollution (Olaniyi, Prause \& Boyesen, 2018). In addition, green jobs must symbolise the quality and stable jobs, sound safety and healthy working conditions, adequate wages and good career perspective as well as ensuring workers' right, social dialogue and protection (Lee \& Nam, 2017). This has made it important to find out if major emissions (SOx and NOx) control measures will yield positive health impact for the seafarers

Occupational safety issues in maritime sector have been discussed from the point of maritime accidents (Akyuz \& Celik, 2014) analysis and prevention (Håvold, 2005) and safety culture assessment (Forsell et al., 2016; Nævestad, 2017). A number of previous studies (Antão et al., 2016; Devanney, 2009; Nævestad, 2017) demonstrated that maritime safety depends on humans, organisations and technical components of the ship system, the marine environment factors as well as in the implementation of the proactive safety management system. In spite of this, there are still limited studies on occupational health especially regarding their health risks assessment when compared to other sectors. This is surprising since conventionally, shipping is perceived to be a relatively dangerous industry that requires proper management of its occupational health and safety, security and environmental issues that are focused on risk assessment and analysing control measures (SIRC, 2018; Talja, 1999; Antão et al., 2018).

In order to prevent risks or to be able to handle them, an efficient risk management process has to be implemented and which is based on the generic management process. This encompasses the following steps: risk identification, analysis, control and mitigation. The risk identification step is often considered as the most important step since only the identified risks can be managed (SIRC, 2018). Risk analysis, especially in transportation sector, involves the identification of the risks, the assessment of the gathered risks and the indication of likelihood occurrence and the possible damage (Schröder \& Prause, 2015, 2016; Tvaronavičienė, 2018).

The risks are further prioritised in the order of risk management. Methods supporting risk identification and analysis are commonly brainstorming and the failure mode and effects analysis (FMEA).

In this vein, the research aims to identify the health risks associated with working on ships by exploring what characterizes as hazards or risks introduced by being a maritime worker in the Baltic Sea Region. It further examines if and how the SECA regulations have influenced the health status in the BSR and especially highlighting the conditions of seafarers. The result has the potential to enhance the understanding of enabling and inhibiting factors that can foster ensuring the safety and wellbeing of maritime workers. 


\section{ENTREPRENEURSHIP AND SUSTAINABILITY ISSUES}

ISSN 2345-0282 (online) http://jssidoi.org/jesi/ 2019 Volume 7 Number 1 (September) http://doi.org/10.9770/jesi.2019.7.1(1)

The work is organised as follows: after the introduction, the next section is the literature review importance of emissions regulations, the identification of the occupational health and safety indicators and environmental factors in ports area and in shipping vessels. Then, the system of methods used for this research is described which is followed by the analysis of the primary and secondary data complemented by expert interviews and analyses of occupational accidents cases. The results and their implications are discussed in section four. The conclusions are presented in the last session.

\section{Literature Review}

Maritime working environment faces physical, ergonomic, chemical, biological, psychological and social factors that may be responsible for occupational diseases, accidents and other harm (Pukkala, 2009). The shipping industry as a complex system - a closed 'social milieu' with all necessary competence on the board (Hetherington, Flin \& Mearns, 2006; ILO, 2013) encourages unusually long period aboard exposing the workers to heavy workloads, long shifts, demanding working conditions, isolation, rigid organizational structures and high levels of psychological stress and physical fatigue (Repka, 2018; Rosendahl, 1998).

SOx and NOx emissions from shipping activities both on the ships and the ports not only cause various harmful effects on human health, they affect agricultural crops, ecosystems and material corrosion, and in turn, reduce the actual supply of labour, increase the user cost of capital and decrease productivity. The social costs of these emissions are the costs estimates of the monetized damages associated with their harmful effects (Sanchez \& Poschen, 2009).

In the shipping industry, the enforcement of the legislative framework is complex and weak due to the organisational international structure that includes more than 50 International conventions of Maritime Organisation (IMO) and International Labour Organisation (ILO). As a result, the European Framework Directive on Safety and Health at Work (1989/391/EEC) establishes the general principles for managing safety and health (Moreira, Vasconcelos \& Santos, 2017). Yet, according to Knapp and Franses (2009), there are still limited data about applications of the relevant guidelines for practice.

Occupational health and safety issues are usually subsumed into environmental and social risks. Diverse studies i.e. Hetherington et al. (2006); Antonsen (2009) and Nævestad (2017) have addressed the different issues within maritime safety and security and have demonstrated the importance of the effective combinations of different related factors. These factors will help to build the framework for the identified risks and include; human factors, organisational factors (social organisation of the personnel on board, operating level), economic pressure, teamwork, social skills, knowledge and training, languages skills, situation awareness, decision-making, communication, automation and technological innovations and safety culture.

Accordingly, taking a bottom-up approach, the authors, clustered the risks in categories that describe their risks sources. The main categories were chosen in accordance with the three pillars of sustainability, i.e. Environmental risks, social risks and economic risks used by Schröder and Prause (2015; 2016). This encompasses the environmental risks the workers are subjected to, the health risks of the population impacted by shipping operations and the safety issues of maritime workers onboard or ashore.

Occupational Environment: Operations, facilities and different activities may create adverse effects on the environment (Antão et al. 2016), thus effective maritime environmental management needs to focus on the potential impact of the work environment on occupational risks. In the BSR, cancer has been said to be very common among ship workers compared to land-based occupations, especially lung cancer and mesothelioma. More so various general diseases such as cardiovascular diseases, work-related stress and depression, hearing impairments have also 


\section{ENTREPRENEURSHIP AND SUSTAINABILITY ISSUES}

ISSN 2345-0282 (online) http://jssidoi.org/jesi/ 2019 Volume 7 Number 1 (September) http://doi.org/10.9770/jesi.2019.7.1(1)

been diagnosed among seafarers (Reinhold, Järvis \& Tint, 2015). Studies have also highlighted the negative safety effects of stress, fatigue, manning level, alienation and heavy load as the essential causes of operation errors common in maritime transport (i.e. Allen, Wadsworth \& Smith, 2008; CEEH, 2011). Collisions, fires/explosions, personal occupational accidents, homicide, suicide and diseases are also major occupational hazards for seafarers (Hetherington, Flin \& Mearns, 2006).

Occupational Safety: Occupational accidents in maritime sector include human factors, prevention measures and interventions (ILO, 2013; Moreira, Vasconcelos \& Santos, 2017), which is an important subcategory of social risks that represents "safety deficiencies" due to unknown safety regulations or/and lack of awareness about the relevant regulations or different legal systems (also called "lack of knowledge") (Transport \& Environment, 2017). It further includes safety issues of maritime workers onboard or ashore that embraces the exposure to shipping emissions like the SOx and the NOx.

Occupational Health: Healthy workers are a vital prerequisite for social, environmental and economic development and sustainability (Olaniyi, Atari \& Prause, 2018; Atstaja et al., 2017; Bernardi, 2019).

The benefits of having healthy workers and safe working conditions are related to the high possibility to recruit skilled workers, an increase of labour productivity and workers' motivation, increased operational performance and reduced social and economic costs of occupational accidents and diseases (Barregard et al., 2019; Schröder \& Prause, 2015).

Taking into account these issues, green jobs should be decent; in particular, they should be a healthy and safe environment most especially for the workers' health and their well-being (Schröder \& Prause, 2016).

A conspicuous gap in the maritime sector is the lack of reliable and comparable data on the exposure to occupational hazards of the workers, how the possible occupational health risks-safety regulations integrate the everyday operation management into the complex legislative framework, and how this framework is implemented to ensure safe and healthy working environment (Transport \& Environment, 2017). According to WHO, a surveillance system in the field of occupational health must collect, analyse and integrate data which enables monitoring workers' health and ensure early detection of significant change caused by working conditions, environment and pollution, an organization of work (Olaniyi, Atari \& Prause, 2018). In other words, occupational health and safety (OSH) systems in different countries must be able to integrate different activities such as workers' health surveillance (analysis of mortality, occupational disability, occupational accidents and diseases, absenteeism, lifestyle and unhealthy behaviour), and monitoring of working conditions (risk assessment and management) and the first step to this is the identification of the associated risks.

\section{Systematic accidents analysis in the theory and in practice}

The system approach is needed in order to analyse accidents and to find and to understand the of accidents causation. However, a number of studies have demonstrated that the most occident reports are focused on cause-effect models perspective and sometimes not allow the development of more effective and adequate safety precautions (Underwood \& Waterson, 2013; Leveson, 2011).

In addition, previous studies suggests that existing systematic accidents analyses techniques are yet accepted by the outside of the safety research (Samuel, 2010), what involve insufficient resources provided for the investigation, a lack of the method reliability, because of the qualitative approach in several existing systemic analyses models (Underwood \& Waterson, 2013) as well as the investigator bias (Lundberg, Rollenhagen \& Hollnagel, 2010) and, thus, a research-practice gap exists in accidents analyses. 


\section{ENTREPRENEURSHIP AND SUSTAINABILITY ISSUES}

ISSN 2345-0282 (online) http://jssidoi.org/jesi/ 2019 Volume 7 Number 1 (September) http://doi.org/10.9770/jesi.2019.7.1(1)

\section{Methodology}

\subsection{Sampling strategy}

The current study is the first study regarding OSH in shipping in one of the Baltic States (Estonia) and therefore, the multi-method approach has been applied. The techniques used in the current research involves two approaches: (i) a top-down approach, what was based on the relevant legislation and regulation as well as interviews from the experts in the field of shipping and occupational health and safety; (ii) a bottom-up approach, what involved indepth analyses of different indications on the topic of OSH and Environment as well as extended analyses of the cases of the occupational accidents investigations

A literature review identified the existing research gap for this study and it targets identifying risks and their impact on health and work safety of sea workers in the context of the SECA regulations and the forthcoming NECA regulations. For this purpose, the research design constitutes as follows:

The primary empirical evidence in this paper is based on the qualitative research approach according to Talja (1999). Here, the complexity of the research requires personal interviews because risk management addresses a sensitive issue of a workplace and it was important to build trust with the different respondents for data gathering. The multimethod approach consisted of using expert interviews and multiple case studies of occupational accidents. All together 25 cases of occupational accidents in the ships were analysed. The data were collected during the period of 2013-2018 and 2019. The main research methods were document analysis (critical discourse analysis).

\subsection{Participants and design of interviews}

Interviews were conducted with five experts in the field of maritime OSH: occupational health physician (Int 1), labour inspector specialized in the maritime sector (Int 2), a statistician in occupational accidents and diseases from Labour Inspectorate (Int 3), and head of the Estonian Seamen's Independent Union (Int 4) and a safety manager (an employer's representative) (Int 5). The purpose of these interviews was to gain detailed knowledge on working environment, health and safety of maritime workers, identify potential risk factors and ways to manage them, gather data on possible and actual health problems and identify the steps towards progressive improvement in the field of $\mathrm{OSH}$. The interview questions were designed in order to explore current shortages of the OSH system in maritime sector as well as understand the following topics: (1) the experts' knowledge about relevant national and international legislation (e.g. SECA), (2) the awareness about the current OSH situation and possible accident causation, (3) the possible barriers of the effective safety management system in the maritime sector, particular in ships, (4) the main occupational hazards and health risk of the employees, (5) possible good practices in safety management system in maritime sector.

The interviews were conducted by two experienced university researchers in Estonian language. Each interview lasted about 50 minutes on average.

\section{Results and discussion}

The current section begins with a description of risk awareness from working on ships and OSH knowledge. Then, we present the analysis of the different OSH management practices and report the main occupational hazards based on the results from the interviews with experts. This is followed by an account of key findings about risk prevention and the role of external experts and OSH service providers in enhancing environment, health and safety in the maritime sectors. The last element of the account of the key findings concerns possible barriers, routines ensuring safety and health work and good OSH practices as well as what determines the arrangements for effective environmental and OSH management practice in the context of Estonian maritime sector. 


\section{ENTREPRENEURSHIP AND SUSTAINABILITY ISSUES}

ISSN 2345-0282 (online) http://jssidoi.org/jesi/ 2019 Volume 7 Number 1 (September) http://doi.org/10.9770/jesi.2019.7.1(1)

\subsection{Occupational risk awareness and perceptions from working on a ship}

Risk awareness may be affected by the level of education and training received and skills developed by the employer and workers in the maritime sector; commitment of the top-management to safety; an ability and possibilities of experienced workers to transfer the good and safe work routines to younger and unexperienced workers, the role of external OSH providers and experts as well as the level of control and supervision performed by the external authorities, for example by the Labour Inspectorate. Risk awareness and general knowledge about occupational hazards in the maritime sector is based on the experience of the workers and/or education received by workers at the maritime schools (mainly technical personnel), however the majority of the personnel are workers, particular service personnel, who need to recieved adequate safety training.

Based on results of interviews with experts, it is possible to say, that risk awareness at a general level among employers and workers is good, there are aware of the main occupational risks and preventive measures.

The interviews with all specialists emphasized the work in the maritime sector as is one of the most challenging and hazardous occupations.

The current study is the first step in addressing all these issues in the maritime sector by applying the bottom-up clustering approach (i.e. occupational environment, safety and health), sources of the identified risks are categorised as follows:

Occupational Environment: According to the data from the interviews with the statistician and occupational health physician, the major health risks associated with occupational diseases among seafarers are musculoskeletal disorders (MSD) caused by physical strains, repetitive movements and compulsory postures. MSDs are generally injuries and disorders that affect the human body's musculoskeletal system (i.e. muscles, tendons, ligaments, nerves, blood vessels, etc.). An employer's representative (Int 5) also confirmed this findings by describing common MSDs in their company:

'We have several cases of the diagnosed occupational diseases caused mainly by repetitive movement and physical strains. The most common diagnoses MSD is carpal tunnel syndrome among service personnel. Workers are complaining about high physically and psychologically strenuous work and we are trying to deal with it by providing different training and instructions' (Int 5)

In addition, the category of occupational hazards also includes noise and vibration, especially during the winter time, because of icy conditions, and while arriving at the port or leaving it. Workers can be also exposed to chemicals, from exhausts and skin contact with oils. During maintenance of the ships, toxic paints and solvents are often used with no special attention of their toxicity to health. The latter was indicated also by labour inspector who stated:

'During the check-ups I have noticed that seafarers use paints in packages without correct labelling or absence of material safety datasheet. Workers are not familiar with health hazards those paints and solvents can cause'.

(Int 2)

Occupational Health: In Estonia, occupational health services (OSH services) are provided only by private companies, what constitute an important infrastructure which provides not only expert advice and counselling to the employers and the workers, safety training, but also institutes preventive and control actions in the field of health and safety at work, such as risk assessment and health surveillance (health check-up). 


\section{ENTREPRENEURSHIP AND SUSTAINABILITY ISSUES}

ISSN 2345-0282 (online) http://jssidoi.org/jesi/ 2019 Volume 7 Number 1 (September) http://doi.org/10.9770/jesi.2019.7.1(1)

However, the interview with occupational health physician (Int 1) revealed that the ordinary health check-ups (to receive health certificate for working in the maritime sector) do not examine the workers' health problems in-depth. The examination takes place every 2 years and is largely based on the worker's health declaration. During the visit that usually lasts for about 30-45 minutes depending on patient and problems, visual checks, audiometry, blood and urine tests are conducted. When serious problems are detected, the occupational health physician involves specialists.

The toxic damages from chemicals are tracked with haemogram with leukogram (hB-CBC-5Diff). When changes are detected, medically, the reason behind may be complex making it difficult to conclude if the changes have occurred because of the working environment or a person's lifestyle. Toxic damages are detected from urine sample as well - changes in liver and/or kidney functions are indications of health problems but also remain unclear whether the changes have occurred due to alcohol consumption or from exposure to toxic chemicals at work or in the environment. In the vessels, there can be various occupational exposure to toxins and chemicals, which may contribute to cancer development. There are, however, only a few cases per year when the seamen's health indicators do not meet the requirements but the differences are detected because of serious diseases like diabetes, cancer, liver and kidney failures or hearing impairment or visual impairment. At the same time, regarding regular health check-ups the employer's representative reported:

'We are conducting the risk assessment by ourselves and based on its results we organize regular medical examination and assessment of workers' health conducted by occupational health physicians. However, I do not highly value the prevention role of this formal procedure and the feedback and recommendations received after

health surveillance provided by occupational health physicians. It is very seldom when we receive some restrictions, for example, some worker does not fit for the work or valuable advices what need to be done or improved in the working environment. In the large passenger ship, there is also a healthcare worker, whose role is to serve passengers.' (Int 5)

Occupational Safety: Our research confirmed previously known situations in occupational safety in the ships. Occupational accidents mainly occur while slipping, tripping and falling (sprains, dislocations, strains), while doing manual handling of loads (mainly back injuries) or working with chemicals (mainly dermal corrosions or eye damages). Interview with labour inspector revealed that there is a lack of resources to conduct comprehensive inspection over the compliance with requirements of OSH in the maritime sector:

'It takes enormous time to carry out the inspections on ships. We can reach only those who sail close-by and hardly manage to control ships which are farer away. We do not know what conditions occur on those ships; usually we get feedback only through the accident reports'. (Int 2)

The head of the Estonian Seamen's Independent Union confirmed the statement and added that working conditions are observed only occasionally while the most complicated conditions occur during arriving at the port.

In larger vessels, the safety management is usually efficient and regular working environment monitoring is evident but in smaller vessels, the conditions may be considerably harder and workers may be exposed to different health risks. During the interview, labour inspector stated the main shortage in occupational safety:

'Considering occupational safety, I can say the main shortage: lack of safety instructions. One good example is a towing vessel. I have experienced several times that there is no safety instruction about towing even when it's known as a very hazardous activity'. (Int 2) 


\section{ENTREPRENEURSHIP AND SUSTAINABILITY ISSUES}

ISSN 2345-0282 (online) http://jssidoi.org/jesi/ 2019 Volume 7 Number 1 (September) http://doi.org/10.9770/jesi.2019.7.1(1)

Consequently, it means also lack of personnel safety training and common understanding about safe behaviour while doing the job. At the same time, an employer representative, claimed that all health risks are under the control in the ships, because of the regular safety training of top-management and workers:

'All risks are under the control, because we have conducted an effective three-days safety training for topmanagement. In addition, the structure and clear instructions support good safety performance. The level of workers' safety knowledge is also high and they notice and report deficiencies in the safety management system. '

(Int 5)

Quality of workplace risk assessment: On ships, similar regulative requirements are valid as for other working environments: enterprises have to conduct risk assessment and notify the employees of the occupational hazards, the results of risk assessment and of the measures to be implemented in order to prevent damage to health. According to labour inspector, the content of risk assessment is often weak:

'During the visits on the ships, I always start with analysis of the risk assessment to get the better overview of the working conditions on this particular ship. The quality is varied. The main shortages are inadequate levels of risk, absence of assessment of certain occupational hazards, weak connection of usage of personal protective equipment and outcomes of risk assessment. I feel that ship owners do not perceive the importance of risk assessment in order to avoid occupational accidents and diseases'. (Int 2)

This was also confirmed by the occupational health physician:

'The quality of existing risk assessment varies. It is possible to say that the main weaknesses of the risk assessment are absence of exposure assessment (measurements), unsystematic evaluation and assessment of health risks as well as insufficient assessment of psychosocial and chemicals risks, as well as absence of exposure assessment. In comparison to the manufacturing sector, the family doctor can also conduct workers' health examination in the maritime sector. In this situation, sometimes, it means, that workers' health examination is performed without necessary relation to risk assessment and exposure assessment of the hazards in the workplace.' (Int 1)

When the researchers asked employer representative more precisely about the cooperation with occupational health doctors and possible benefits of conducting health surveillance for workers, employer representative could not name any benefit or expected specific outcome.

Additionally, employer representative has demonstrated good awareness about the legislative requirements (e.g. rights and responsibilities of workers and employers, risk assessment, health surveillance, safety training and instructions, occupational hazards, personal protective equipment, etc.) and stated that chemicals measurement are conducted on the ships and in the port area, but the main focus on environmental issues and not on occupational exposure of workers.

To the question about risk assessment and control measures implemented in order to minimise health risk of chemicals on the ships, an employers' representative (Int 5) has stated that:

'...the system of using of chemicals on the ships are mainly closed system and our workers are all an experienced workers and do their work carefully, what greatly minimise the risk of exposure and possible adverse health effects.' (Int 5.)

This finding confirmed previously known situation in the field of OSH in Estonia, that employers and workers have the attitude that workers should deal with hazardous situations themselves - the responsibility is clearly on them as 


\section{ENTREPRENEURSHIP AND SUSTAINABILITY ISSUES}

ISSN 2345-0282 (online) http://jssidoi.org/jesi/ 2019 Volume 7 Number 1 (September) http://doi.org/10.9770/jesi.2019.7.1(1)

individual workers, thus deflecting attention away from organisational issues in the management of the work process (SESAME, 2018). At the same time, it is important not to overestimate the sustainability and generalisability of this OSH knowledge in terms of its organisational embeddedness.

This findings are on a line with other studies (Antão, Calderón, Puig, Michail, Wooldridge, Inov, Darbra, 2016; Zhen, 2018) that demonstrated the importance of proper management of occupational health and safety, security and environmental issues what requires to continually monitor risks, to set up the indicators in order to assess the safety performance.

\subsection{Systemic accidents analysis: human and organisational factors, examining the gap between theory (research) and practice}

A number of studies have identified the systems approach in socio-technical system accidents as separate parts in accident analyses and human factor research (Underwood \& Waterson, 2013). Hassel with colleagues (2011) identified the underreporting of maritime accidents as a problem for authorities trying to enhance safety through the relevant legislation, as well as fo other stakeholders using statistical data and analysis of the accidents for decisionmaking process.

One of the essential safety indicators regarding safety performance on the ships can be the number of accidents, incidents and near misses. For the current study we analyse 25 cases of the occupational accidents in Estonian maritime sector.

While examining the occupational accidents reports, it was revealed that no fatal accidents have occurred during the last 3 years. Half of the accidents resulted with minor injuries and half of the accidents with serious injuries (such as bone fractures, hand injuries with machines with sharp or rotating parts, burnings, serious back injuries etc). Many of the accidents have occurred because slipping, tripping and falling. 24 ships out of 25 confirmed that they have completed the workplace risk assessment, yet, the accident occurred. Many reports said that the reason lies behind worker's incautiousness, carelessness, violation of safety rules, loss of control over the equipment, wearing no appropriate personal protective equipment. To conclude, maritime companies often blame workers on accidents occurring rather than finding root causes and weaknesses in management activities to ensure safe workplaces in ships. While examining the length of employment, the investigation revealed that about two third of the accidents occurred during the first 2 years of working when the seamen have likely not gained enough experience about safety and work practices in difficult conditions and may have not reached to the full proficiency, yet. A few accidents occurred in $11 \ldots 17$ years of employment where seamen may have lost the attentiveness in routine work. To conclude, it is possible to say that one of the essential findings from the analyse of the investigations of occupational accidents and interviews is that occupational accidents mainly occur while slipping, tripping and falling. The main causes of the accidents identified in the official investigation reports were (1) breach of safety requirements by employee, (2) difficult weather conditions, (3) wet or uneven surfaces and (4) improper training.

In addition, some other studies have demonstrated the important of the systematic investigation process of accidents and the essential role of human and organisational factors in maritime accidents (Chauvin, Lardjane, \& Morel, 2013; Ergai, Cohen, Sharp, Wiegmann, Gramopadhye, Shappell, 2016).

Results from interviews with experts from Labour Inspectorate and Estonian Seamen's Independent Union, and employer representative claimed that compounding these barriers is the fact that many hazards and risks are automatically accepted as a part of the job, and no complaints made when a minor accident happens. It was reported by the expert: 


\section{ENTREPRENEURSHIP AND SUSTAINABILITY ISSUES}

ISSN 2345-0282 (online) http://jssidoi.org/jesi/ 2019 Volume 7 Number 1 (September) http://doi.org/10.9770/jesi.2019.7.1(1)

'It seems that the responsibility for safety is clearly dedicated on individual worker on the ship. Both, employers and workers have the attitude that workers should deal with hazardous situations themselves and minor accidents are not reported and investigated. Only formal requirements are met from the organisational issues in the management of the work process.' (Int 4)

\subsection{SECA Regulations and Air Quality Measurement Result}

Regarding the impact of the SECA regulations on the health and safety of the maritime workers, the empirical results of the EnviSuM project revealed new results. Barregard et al. (2019) made investigations in the port area of Gothenburg using the measurement results during the project at different places and were able to estimate the number of reduced extra deaths due to SOx emissions in BSR to be about 1000 deaths. Germany and Russia are the countries with the highest numbers of reduced deaths due to their high population. All in all, the results of the "EnviSuM" project detected an increase of the air quality within BSR and the reduction of the annual emission of Sulphur into half.

An important part of the EnviSuM project work is dedicated to the study of the socio-economic impact of the SECA regulation by measuring air quality together with the evaluation of these impacts. In work package 3 of the project a collection of air quality measurements in the pilot cities of Gothenburg in Sweden, the Tricity (Gdansk, Sopot and Gdynia) in Poland and St. Petersburg in Russia will help to assess the effect of the new legislation. The air quality measurements were made for a 6 month navigation season in year 2016 near the port. In St. Peterburg there will also be a 7 days campaign on a boat. Measured components will include NOx, SOx, CO, PM10, and PM2.5. In order to reach comparability of the measurement results between all pilot cities intercalibration of the measurement equipment will be conducted by the Finnish Meteorological Institute (FMI). FMI maintain the accredited calibration and standard laboratory capable for providing SI traceable calibration service for NOx, SOx and CO measurements.

The investigations of the EnviSuM project also brought to the limelight that the air quality in BSR improved by at least 70\% after the enforcement of SECA regulations. Repka, (2018); Jonson, (2018) gave a detailed analysis of the results that show a decrease in air pollution from shipping to be $71 \%$ in Norway and around $6 \%$ in Russia. In total, the sulphur deposition in the BSR has decreased by 50\% from 2014 to 2016. Borkowski (2017) analysed the air quality in the urban area of the Polish Tri-city (Gdynia - Sopot - Gdansk) and calculated the SOx pollution caused by port operations from ships and identified significant reduction in SOx concentrations in close ports areas which are up to 20 times higher than in distance-port areas affirming that close proximity to shipping increases exposure to pollutants.

Over 3 years after the SECA regulations implementation in the BSR, a renew focus is now on the 2020 global Sulphur limit, a law which affect a wider audience and culture than the SECA. Hence, it is important to point out the results of Lähteenmäki-Uutela et al. (2019) who were able to show that the SECA regulations spurred the innovations of clean and environmental technologies of BSR economy so that BSR companies possess a vanguard position of clean shipping technology bearing the opportunity that from 2020 the BSR may become an important export region for clean shipping products all over the world. Thus, the OHS improvements of seafarers from BSR might be also exported with the start of the global sulphur limit from 2020.

\section{Conclusion}

This paper attempted to get knowledge about occupational risks for seafarers in the BSR. The study revealed the different risks the authors classified using a bottom-up clustering approach of potential sources from the environmental sustainability standpoint i.e. environmental (occupational environment), social (occupational safety) and economical (occupational health), a new contribution to the industry. 
The results of the "EnviSuM" project showed only neglectable impact of SECA regulations on BSR logistics sector and no evidences for modal shifts or changes in transport patterns in BSR. Hence, the end result of the SECA regulation is positively different from the widly publisied sceptisim before 2014. On another handside, the study further confirms that even though proximity with the source of pollution determine the level of exposure and increases occupational health and safety risk, the SECA regulation may have positively improved the health and safety of maritime workers since the air quality in BSR has improved by at least $70 \%$ after the enforcement of the regulations.

The study results have also demonstrated the importance of a holistic approach to occupational health and safety, environmental issues in the maritime sector. These issues are essential not only to comply with relevant legislation and requirements but also to diminish possible costs and to safeguard the environment, and ensure a healthy, and safe working environment. The causes and mechanisms behind the most serious cases would certainly need further clarification and future research should also include maritime risks prioritisation and handling management.

\section{Acknowledgements}

This work is a part of the ongoing EnviSuM (Environmental Impact of Low Emission Shipping: Measurements and Modelling Strategies) project sponsored by the European Regional Development Fund. The referred results of the EnviSuM project have been elaborated by the EnviSuM consortium and belong to all project members.

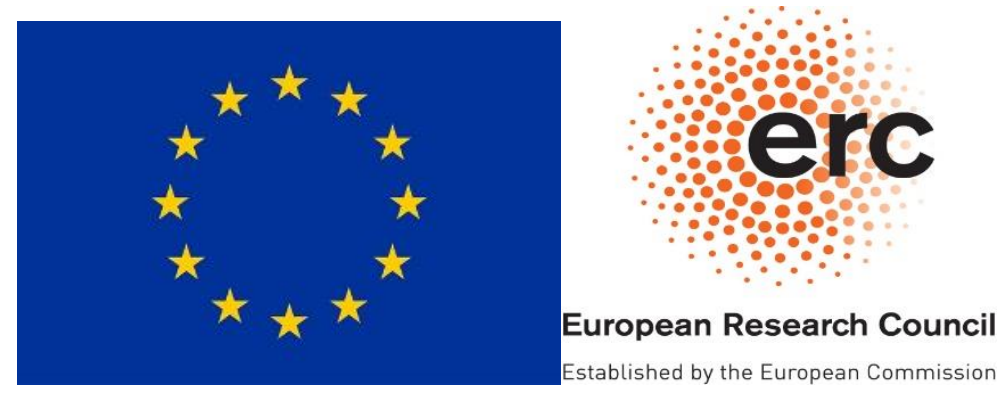

\section{References}

Akyuz, E., Celik, M. 2014. Utilisation of cognitive map in modelling human error in marine accident analysis and prevention. Safety Science, $70,19-28$.

Allen, P., Wadsworth, E., Smith, A. 2008. Seafarer's fatigue: a review of the recent literature. International Maritime Health, 59: 81-89.

Antão, P., Calderón, M., Puig, M, Michail, A., Wooldridge, C., Inov, Darba, R.M. 2016. Identification of Occupational Health, Safety, Security (OHSS) and Environ-mental Performance Indicators in port areas. Safety Science, 85, 266-275.

Atari, S., Bakkar, Y., Olaniyi, E.O., Prause, G. 2019. Real options analysis of abatement investments for sulphur emission control areas compliance. Entrepreneurship and Sustainability Issues, 6(3), 1062-1086. https://doi.org/10.9770/jesi.2019.6.3(1)

Atstaja, D., Susniene, R., Järvis, M. 2017. The Role of Economics in Education for Sustainable Development; The Baltic States' Experience. International Journal of Economic Sciences, VI (2): 1-29.

Barregard, L., Molnàr, P., Jonson, J.E., Stockfelt, L. 2019. Impact on Population Health of Baltic Shipping Emissions, International Journal of Environmental Research and Public Health 2019, 16, 1954, https://doi.org/10.3390/ijerph16111954 


\section{ENTREPRENEURSHIP AND SUSTAINABILITY ISSUES}

ISSN 2345-0282 (online) http://jssidoi.org/jesi/ 2019 Volume 7 Number 1 (September) http://doi.org/10.9770/jesi.2019.7.1(1)

Bernardi, A. 2019. The capability approach and organizational climate as tools to study occupational health and safety. Insights into Regional Development, 1(2), 155-169. https://doi.org/10.9770/ird.2019.1.2(6)

Boffetta, P., Dosemeci, M., Gridley, G., Bath, H., Moradi, T., Silverman, D. 2001. Occupational exposure to diesel engine emissions and risk of cancer in Swedish men and women. Cancer Causes Control 12(4), 365-374.

Borkowski, T. 2017. Changes in air quality in the Tri-City (Gdynia, Sopot and Gdansk) related to the operation of seaports and changes in SECA requirements, Mari-time University of Szczecin, EnviSum Project meeting in Tallinn, 11-12 October 2017.

CEEH, 2011. Assessment of Health - Cost Externalities of Air Pollution at the Nation-al Level using the EVA Model System, CEEH Scientific Report No. 3, Roskilde, ISSN 1904-7495.

Chauvin, C., Lardjane, S., Morel, G. 2013. Humana nd organisational factors in mari-time accidents: Analysis of collisions at sea using the HFACS. Accident Analysis and Prevention, 59, 26-37

Devanney, J. 2009. Uses and Abuses of Ship Casualty Data. Centre for Tanker Excel-lence.

Forsell, K., Eriksson, H., Järvholm, B., Lundh, M., Andersson, E., Nilsson, R. 2016. Work environment and safety climate in the Swedish merchant fleet. Int Arch Occup Environ Health, 90, 161-168.

Ergai, A., Cohen, T., Sharp, J., Wiegmann, D., Gramopadhye, A., Shappell, S., 2016. Assessment o fthe Human Factors Analysis and Classification System (HFACS): Intra-rater and inter-rater reliability. Safety Science, 82: 393-398

Hassel, M., Asbjørnslett1, B.E., Hole, L.P. 2011. Underreporting of maritime acci-dents to vessel accident databases. Accident Analysis and Prevention, 43: 2053- 2063.

Hetherington, C., Flin, R., and Mearns, K., 2006. Safety in shipping: The human element. Journal of Safety Research, 37, 401-411.

Håvold, J, I. 2005. Safety-culture in a Norwegian shipping company. Journal of Safety Research, 36, 441 - 458.

ILO. Appendix IV: Draft Guidelines concerning a statistical definition of employment in the environmental sector - The nineteenth International Conference of Labour Statistics (ICLS). 2013. Geneva. ILO: 2013.

Jonson, J.E. 2018. Regional Air Quality modelling, XVII International Environmental Forum «Baltic Sea Day», 22-23 March 2016 in St. Petersburg, Russia.

Knapp, S., Franses, P.H. 2009. Does ratification matter and do major conventions im-prove safety and decrease pollution in shipping? Marine Policy, 33: 826-846.

Lähteenmäki-Uutela, A., Yliskylä-Peuralahti, J., Olaniyi, E., Haukioja, T., Repka, S., Prause, G., De Andres Gonzalez, O. (2019). The impacts of the sulphur emission regulation on the sulphur emission abatement innovation system in the Baltic Sea region. Clean Technologies and Environmental Policy, 1-14. https://doi.org/10.1007/s10098-019-01684-2

Lee, T \& Nam, H. 2017. A Study of Green Shipping in Major Countries: In the View of Shipyards, Shipping Companies, Ports and Policies. The Asian Journal of Shipping and Logistics, 33: 253-262.

Leveson, N.G. 2011. Engineering a Safer World. Systems Thinking Applied to Safety. Massachusetts Institute of Technology: The MIT Press.

Lundberg, J., Rollenhagen, C., Hollnagel, E. 2010. What you find is not always what you fix-How other aspects than causes of accidents decide recommendations for re-medial actions. Accident Analysis and Prevention, 42(6), 2132-2139.

Moreira, S., Vasconcelos, L. and Santos, C.S. 2017. Sustainability of green jobs in Portugal: a methodological approach using occupational health indicators. Journal of Occupational Health, 59: 374-384.

Nævestad, T-O. 2017. Safety culture, working conditions and personal injuries in Nor-wegian maritime transport. Marine Policy, 84: 251262. 


\section{ENTREPRENEURSHIP AND SUSTAINABILITY ISSUES}

ISSN 2345-0282 (online) http://jssidoi.org/jesi/ 2019 Volume 7 Number 1 (September) http://doi.org/10.9770/jesi.2019.7.1(1)

Olaniyi, E.O., Atari, S., Prause, G. 2018. Maritime energy contracting for clean ship-ping. Transport and Telecommunication, 19(1), 31-44. https://doi.org/10.2478/ttj-2018-0004

Olaniyi, E., Prause, G. and Boyesen, J. 2018. The impact of SECA regulations on clean shipping in the BSR. In: Ölçer, A, Kitada, O., Dalaklis, D., Ballini, F., (eds) Trends and Challenges in Maritime Energy Management book series of WMU Studies in Maritime Affairs. 6(1), 309-323, https://doi.org/10.1007/978-3-319-74576-3

Prause, G.; Olaniyi, E. O. (2019). A compliance cost analysis of the seca regulation in the Baltic Sea. Entrepreneurship and Sustainability Issues, 6(4), 1907-1921. https://doi.org/10.9770/jesi.2019.6.4(26)

Prause, G., Reinhold, K., Järvis, M., Olaniyi, E., Tint, P. (2019). The Socio-Economic Impact of Green Shipping: A Holistic View from the Baltic Sea Region. Springer Lecture Notes in Networks and Systems 68, 615-624.

Pukkala, E. et al., 2009. Occupation and cancer-follow-up of 15 million people in five Nordic countries. Acta Oncol 48(5): 646-790.

Reinhold, K., Järvis, M., Tint, P. 2015. Practical tool and procedure for workplace risk assessment: Evidence from SMEs in Estonia. Safety Science, Volume 71 (C): 282-291.

Repka, S. 2019. Costs and benefits related to compliance with the SECA regulation, EnviSuM final Conference, 24 April 2019 in Copenhagen, Denmark.

Rosendahl, K.E., 1998. Social Costs of Air Pollution and Fossil Fuel Use - A Macroeconomic Approach, Statistics Norway, ISBN 82-5374542-7.

Samuel, A., 2010. The influence of working environment on workers productivity: a case of selected oil and gas industry in Lagos, Nigeria. African Journal of Business Management, 4(3): 299-307.

Sanchez, AB., Poschen, P. 2009. The social and decent work dimensions of a new agreement on Climate Change: A technical Brief. International Labour Office.

Schröder, M., Prause, G. 2015. Risk management for green transport corridors. Journal of Security and Sustainability Issues, 5 (2), $229-239$. https://doi.org/10.9770/jssi.2015.5.2(8)

Schröder, M., Prause, G. 2016. Transportation of dangerous goods in green transport corridors - conclusions from Baltic Sea Region. Transport and Telecommunication, 17 (4), 322-334. https://doi.org/10.1515/ttj-2016-0029

SESAME, 2018. Safety and health in micro and small enterprises in the EU: Final report from the 3-year SESAME project. European Agency for Safety and Health at Work https://osha.europa.eu/en/tools-and-publications/publications/safety-and-health-micro-and-small-enterpriseseu-final-report-3/view Accessed: 01 April 2019.

Shabunina, T.V., Shchelkina, S.P., Rodionov, D.G. 2017. An innovative approach to the transformation of eco-economic space of a region based on the green economy principles. Academy of Strategic Management Journal, 16(1): 176-185.

SIRC, 2018. Studies on the various issues related to the transnational composition of ship crews are available on the Seafarers' International Research Centre website, http://www.sirc.cf.ac.uk/SIRC_free_online_reports.aspx Accessed: 01 May 2018.

Talja, S. 1999. Analyzing qualitative interview data: The discourse analytic method. Library \& Information Science Research, 21(4), 459477.

Transport \& Environment. 2017. Air pollution from ships, https://www.transportenvironment.org/what-we-do/shipping/air-pollutionships, 28.06.2018

Tvaronavičienè, M. 2018. Toward efficient policy making: forecasts of vulnerability to external global threats. Journal of Security and Sustainability Issues, 7(3), 591-600. https://doi.org/10.9770/jssi.2018.7.3(18) 
Underwood, P. \& Waterson, P. 2013. Systematic accidents analysis: Examining the gap between research and practice. Accidents Analysis and Prevention, 55, 154-164

Zhen, L., Li, M., Hu, Z., Lv, W., Zhao, X. 2018. The effects of emission control area regulation on cruise shipping. Transportation Research, Part D, 62, 47-63.

WHO, 2012. Health in green economy: Measuring health gains from sustainable de-velopment. Geneva: World Health Organisation - Public Health and Environment De-partment, Health Security \& Environment Cluster.

\section{Acknowledgements}

This work is in principle linked to the EnviSuM - Environmental Impact of Low Emission Shipping: Measurements and Modelling Strategies project sponsored by the European Regional Development Fund.

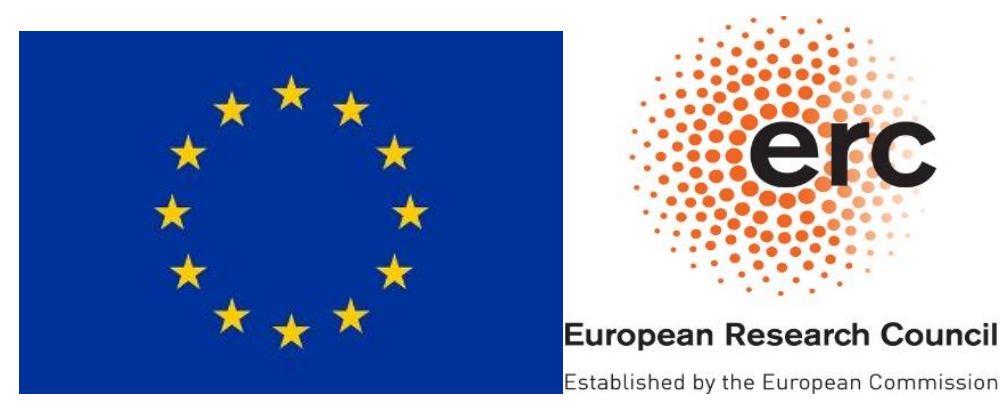

Karin REINHOLD, PhD is the Associated Professor in Working Environment Research Group at Tallinn University of Technology. Her research interests are safety management systems, chemical hazards and occupational toxicology and SME health and sagety good practices. ORCID ID: orcid.org/0000-0003-3608-2354

Marina JÄRVIS, PhD is the Associated Professor of in Working Environment Research Group at Tallinn University of Technology. Her research interests are safety management systems, leadership, knowledge management and work relations.

ORCID ID: orcid.org/ 0000-0002-4541-4632

Gunnar PRAUSE is Professor of Business Development at Tallinn University of Technology. His research interests are entrepreneurship, sustainable supply chain management and innovation.

ORCID ID: orcid.org/ 0000-0002-3293-1331

Copyright (C) 2019 by author(s) and VsI Entrepreneurship and Sustainability Center

This work is licensed under the Creative Commons Attribution International License (CC BY).

http://creativecommons.org/licenses/by/4.0/

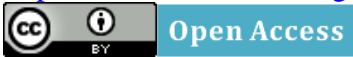

